\title{
OBITUARY
}

\section{AleXander Dewar Williamson}

It is with regret that we record the premature death of Alexander Williamson, until recently senior ophthalmic surgeon and physician, Singapore, and lecturer in ophthalmology at the University of Malaya.

Alex Williamson, the son of a Glasgow seedsman, was educated at the High School and University of Glasgow. Before joining the staff of the Glasgow Eye Infirmary in 1928, he served as house surgeon and house physician in the Western Infirmary. In the seven years in which he was on the staff of the Eye Infirmary, his abilities as an ophthalmic surgeon developed rapidly. He displayed considerable gifts as a junior, gaining his D.O.M.S., and becoming a Fellow of the Royal College of Surgeons of Edinburgh at the first attempt.

His first experience of work in the East was obtained in a 6 months' operating tour with Dr. McPhail's Mission Hospital in India, where he obtained a vast experience in intraocular surgery.

In 1935 he was appointed ophthalmic surgeon and university lecturer in Singapore, so that most of his working life has been spent in Malaya. He established the School of Ophthalmology in Singapore under considerable difficulties, in a country of a multi-racial population striving in recent years towards independent nationhood. In early days he ran his department alone; later, he trained a succession of Asian medical officers, encouraging each in turn to seek higher qualifications in Britain.

The department, which began with a few beds scattered throughout a general hospital, now consists of a large, up-to-date, air-conditioned unit, with about eighty beds.

During the Japanese occupation he continued his work among the local population for over a year, subsequently, and with relief, being interned with his fellow civilians until the liberation. His early death may be attributed, in part, to this internment. It is characteristic of the man that he returned immediately after only a short leave to carry on his work in Singapore.

In 1949 the Army Council appointed him an honorary consultant to the army in Singapore. He was also consultant to the Singapore Association for the Blind and a member of its Executive Committee.

Post-war operative pressure was very great both in Singapore and in the Federation. The number of medical students at the University of Malaya has been increased so that teaching has become an essential part of the work of the department.

In April, 1957, Williamson elected to retire; by this time his department had become completely Malayanized and was staffed by his former students.

Williamson was not a man who wrote, all his energies being devoted to the creation of the Ophthalmic School in Singapore, but the hospital, there, is a monument to him. After. the war he worked on the problem of neonatal keratomalacia. In Singapore this occurred not only in under-nourished and marasmic children, but also in apparently well-nourished infants, whose only dietary defect was vitamin A deficiency. His work with Dr. P. C. Leong of the University of Malaya led to the fortifying of all tinned and dried milks sold in Malaya with vitamin A, and has banished the disorder from the Dominion.

He was also an acknowledged expert on trachoma.

Only a man with his driving energy could have coped with this increasing pressure of work, which left little time for publishing cases and results or for research work. He was an excellent linguist, very widely read, and his mind was stored with valuable information covering a vast field. He was good-natured and kindly, with a characteristic 
forthrightness and directness which were sometimes, in his early years, misunderstood. He greatly enjoyed his work, and loved, particularly, the old Chinese women with their direct, quite unabashed claim for immediate attention. Many youngsters were helped in their schooling, and many old people will miss his cheerful badinage in Malay or a mixture of Chinese dialects.

He is survived by his wife, also an ophthalmologist, who greatly assisted him in the early post-war years in the academic side of his work.

\section{DR. KASHMAHINDER SINGH WRITES:}

It is with deep sorrow that I came to know of the sudden departure of my Chief. I find it difficult to believe, for he was young and so full of life.

Mr. Williamson was a great man with a big heart, and one to whom I owe so much. I feel lost without his kindness, help, and guidance. He had a great fondness for children, and his cheerful manner will be most missed by them. He was a gifted speaker, and had a warm and charming approach, especially to his staff and colleagues. His great interests were keratomalacia and trachoma. He served Singapore well, treating thousands of patients who will feel his loss.

\section{WiLliam SimpSON BURR}

The death of Mr. W. S. Burr occurred suddenly at his home in Plymouth on August 5, 1957 , from a recurrence of coronary thrombosis. He was 58 years of age. Mr. Burr was born in Bo'ness, West Lothian, and studied medicine at Edinburgh University, whence he graduated M.B., Ch.B. in 1921; in 1925 he obtained the D.O.M.S., and he was elected F.R.C.S. Ed. in 1927. During this period he held appointments at Bury Infirmary and Derbyshire Royal Infirmary, and latterly became senior house-surgeon at. Moorfields Hospital. In 1927 he settled in Plymouth where he was honorary ophthalmic surgeon to the Royal Eye Infirmary. Some three years ago he relinquished this post but continued as honorary consultant surgeon. He leaves a widow and a son to whom our sympathy in their sudden loss is expressed. 